\title{
The Millennial Generation Buying Behaviour in Purchasing Houses Case of Modest Housing Industry in Indonesia
}

\author{
Kartini Istikomah ${ }^{1}$ \\ \{tini_sht@yahoo.com $\left.{ }^{1}\right\}$ \\ The Faculty of Economy and Business, Universitas Budi Luhur, Jl. Raya Ciledug, Petukangan Utara, \\ Jakarta Selatan $12260^{1}$
}

\begin{abstract}
The purpose of the study was to examine buying behavior of the Indonesian Millennial Generation in purchasing the lower-income or the modest housing. The variables utilized in the study were Lifestyle, Perception, Motivation, as independent variables, and the Purchase Decision as dependent variable. It applied multiple regression analysis to find determining factors for those all independent variables. The respondents were the owners of the modest houses, the price lower than IDR $250 \mathrm{Mio}$, in Indonesia. The inquiry had done by an on-line questionnaire with google form, been up loaded throughout August to September 2017. The study applied purposive sampling method by controlling the first a hundred responses for the respondent ages of 30 to 40 . The study inferred that the lifestyle or economy factors and motivation or investment factors were the salient factors for the buying behavior in purchasing the modest housing. The perception or the pride factors, however, were not the issues for the millenial to buy it. Most the respondents were evidently the millinial who living in the suburb of the Jakarta Metropolitant Area.
\end{abstract}

Keywords: Consumer behavior, lifestyle, perception, motivation and purchase decision.

\section{Introduction}

Property refers to land, buildings, the attached facilities and the infrastructure surrounding. The building refers to houses, apartments, malls, shops or office buildings [1]. People buy property usualy for an investment, mainly for long-term investment. Investment in property is considered the most lucrative one compared to other investments such as mutual funds, shares, gold or deposits [2]. All due to increasing demand stimulated by the increasing number of people who need housing [3]. The demands affected the prices of the houses which tend to increase lately [4].

In addition on spending of food and clothing, people need investing house for assuring their future. Unfortunately, houses ownership remain obscure for various individuals, even for owning a modest house; this is even more pronounced for the buyers, who born during 1980 1994, commonly referred to as the millennial [3]. Millennial risk of dwindling to own a house in the next five years [5].

The prediction was supported by other analysis asserting that the ability to pay the instalment for buying a house or other spending is at the maximum of $30 \%$ out of the total income [3]. This assumption is described in the calculation as follows: with the monthly 
income of millennial amounting to between IDR 5 million to IDR 7 million, their ability to pay mortgage will be around IDR 2 million. This figure is still affordable according to the mortgage for KPR (House ownership credits) of IDR250 million, with the monthly mortgage of IDR 2 million paid within the duration of 15 years; however, these figures will be impossible in five years later [6]. This fact needs to be of the consideration for developers and government alike to accommodate the millennia's purchasing power. The BPS Indonesia, (2016) recorded that in during next five year, out of the total population of 285 million population, the millennial of the ages from 15 - 39 make the most part of the demography. Indonesia currently enjoys the demographic bonus, where the productive ages outnumber the non-productive ages; it will reach its peak during 2020 - 2030 [7].

With such an advantage, it is important for Indonesia to accommodate the market for this age brackets. Failure to facilitate their house ownership will turn this demographical bonus into demographical burden and will further give adverse economic effect for the country [8]. Some of the events lately confirms the concerns. Developers and the government seem to be unresponsive to address this concern. Government regulations and property development conducted by developers are yet to demonstrate the sensitivity on this market demand [8].

As the evidences the Rumah.com, (2017) during the year 2016 the millennial age, borned during $1980-1994$ - have only minimally been absorbed by the property market. It is recorded that, out of the whole buyers of the previous year, millennial account for $16.80 \%$ of the buyers within that period. The survey by rumah.com titled "Property Affordability Sentiment Index" [9] illustrated that 34\% out of the total respondents of 1,030 declared that the property prices are exorbitant, in other words there exists only minimum property with affordable prices; whilest, $48 \%$ declared that they are not ready to buy property.

In addition to this, other empirical studies also emerged. [10] the quarterly report of the Jakarta Property Market published a number of research related to millennial and property ownership. The research recorded that $80 \%$ of the total 149 respondents being born between $1980-1997$ actually have the plan to buy property this year. Some of the most wanted areas include Tangerang $(21.21 \%)$ and West Jakarta $(21.21 \%)$. Moreover, $38.38 \%$ of the total number of respondents mentioned that the most sensible price of a house is below IDR250 million. When it comes to payment method, $72 \%$ admitted that the most possible method is by paying in installment. A total of $35.9 \%$ admitted that the installment of $8-10$ years are the most realistic.

This statement underlines the fact that although the purchasing power of millennial might be too low to own a property, they actually have significant potentials. Unfortunately, a large number of developers are unaware of the magnitude of millennial potentials. This background brought the author to conduct a study on millennial consumer behavior in buying a property. The author has observed a paucity in similar research that specifically dealt with millennial consumer behavior in buying property. Moreover, the author argues that there are some variables from the millennial consumer behavior that play significant role, and this include lifestyle, perception and motivation.

In relation with the abovementioned context, as well as the interest of millennial consumers to buy property below the price of IDR250 million, the author has the initiative conduct a research on the following topic: Analysis on Millennial' Behavior Towards Purchasing Property (Case Study of Modest House Purchase in Indonesia). 


\section{Scope of Research and Research Objectives}

In order to focus on the object of research, as well as to minimize distraction of focus, the author limits the research to cover the following: the Lower-middle class property or property with prices below IDR250 million and jectives the research object is limited to millennial ages with buying behavior for modest house buying decision. The research was conducted between March - September 2017.

The research questions for the study were as follows: 1) Does the millennial lifestyle affect the decision to buy modest housing? 2) Does the perception factor affect the decision to buy modest housing? 3) Does the motivation factor affect the decision to buy modest housing? 4) Do the factors of lifestyle, perception and motivation simultaneously affect the decision to buy modest house for millennial? The research for the study was to recognize the effect of lifestyle on the decision to buy modest house in Indonesia, the effect of perception on the decision to buy modest house in Indonesia. Further, it was also to determine, which factor is the most influential in decision-making to buy modest house, among the three factors of lifestyle, perception and motivation. The author expects that this research will provide various benefits for many people that include, i.e: for the author, the benefits of this research for the author include knowledge generation, allowing the author to comprehend the millennial behavior in making the decision to purchase a modest house. For developers: The results will serve as input and advice to assist in the decision- making process or the selection of the marketing strategies to provide modest housing for the lower middle class, something that millennial have expressed an interest in. Lastly for readers, the results of the research will inform readers further on the consumer behavior of millennial in purchasing modest housing for lower middle class.

\section{Literature Review}

To support a research, there needs to be a scientific theoretical framework. This theoretical framework is closely related to the research variables used to find the response to the research questions.

\subsection{Marketing}

According to the American Marketing Association (AMA) — in the book written by Kotler and Keller, (2009) marketing is defined as - a series of process to create, communicate and maintain relationship - that gives additional values for the organization and consumers [11]. According to Grewal et al., (2010) marketing is a managerial and social process conducted by an individual or group - to fulfill particular needs or demand - by maximizing creativity, offers, as well as exchange of valuable goods and services [12].

Marketing is further classified into several variables referred to as marketing mix for housing consisting of $4 \mathrm{P}$, i.e: product, price, promotion and place and the substance certaintly all would be modified according the product and the industry in queries [13]. Grönroos, (1984) and Tjiptono, (2002) stated that marketing aims at fostering, developing and commercialize relationship between producers and consumers in order to fulfill their mutual needs; the producers need consumers as their source of income, whereas consumers need producers to fulfill their needs. In Thailand, the most respondents decision to purchase a 
residence in the housing project in Muang District, NakhonRatchasima, was emphasizing every 4-P marketing mix factors including the traffic jam, location, design and well-known constructor were the top factors, while the fitness center and swimming pool were least important for the first housing owners or the milennial generation [14].

\subsection{Consumer Behavior}

As stated by Kotler and Keller, (2009), consumer behavior science is the study on how individuals, groups and organization - choose, purchase and use goods, services, ideas or experience - to satisfy their needs and desires [11]. This is similar to what Gibler and Nelson, (1998) states that consumers behavior is the behavior of consumers who are directly involved in the process of obtaining and using goods and services, including the preparation process to obtain this product or services [15].

The consumer behavior is further classified into several factors that include cultural factor, social factor and psychological factor. Engel, J. F., Blackwell, R. D., \& Miniard, (1995) defines lifestyles as the pattern of using financial resources and time [16]. Krishnan, (2011) expresses similar idea and states lifestyle as the consumption pattern that depict people's choice in using their financial resources and time [17].

The effect of lifestyle on a variable can be simply measured using psychographic analysis. This instrument is used to measure the lifestyle quantitatively using very large dataset. This is usually conducted to view the market segments. This analysis can be the measure of the variables within lifestyle such as activity, interest, and opinion, most commonly abbreviated as AIO. Also, Krishnan, (2011) divides the AIO approach into several dimensions. This approach is commonly used by producers in promoting their products [17].

According to Pickens, (2005), perception is part of the individual process in selecting, organizing and interpreting stimulus to become something that influences the buying decision [18]. Also, Quratulain and Karachi, (2012), asserted that perception is an individual attitude towards appreciating the entire quality and competitiveness of a product; perception can be divided into two, namely quality perception and value perception. Quality perception refers to the evaluation of consumers on product and service that has been purchased or about to be purchased [19]. Value perception is the customer judgemental about being functional, selfexpression and emotional values.

Mohammad and Som, (2010) described motivation as the push factor in individual that compels someone to take action [20]. (Guan, 2014) asserted that motivation is the subconscious state of an individual that propels him/her to act on something to achieve particular objectives [21]. Lee, (2007) asserted that the consumer's motivation refers to a consideration and influence that drives someone to make a purchase [22]. Svatosova, (2013) uncovered that purchase decision, in particularly on line business, refers to consumer action to buy or not to buy a product related to the buyer motivation.

Kotler and Keller, (2009) asserted that the process in which consumers decide to purchase a product is divided into several stages [11]. These stages include need recognition, information search, and evaluation of alternatives, purchase decision and post purchase behavior. 


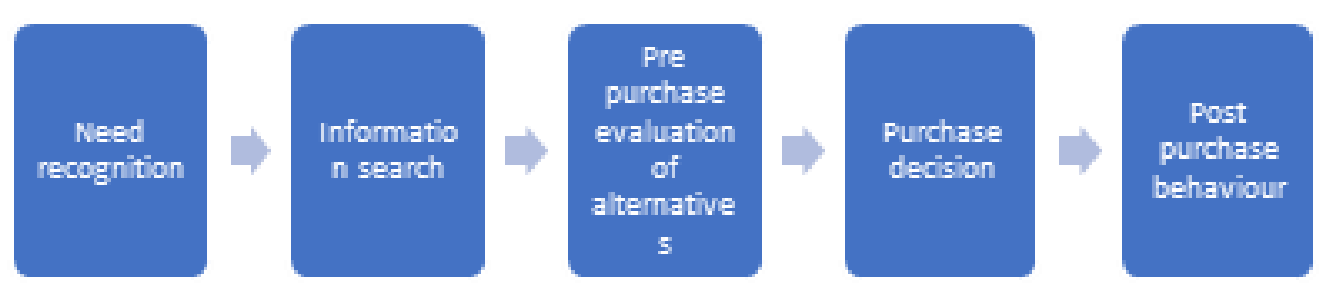

Fig. 1. Purchase Decision Process Model [23]

\subsection{Millennial Generation}

Each generation has their own characteristics. These characteristics are formed as the results of the changes brought by modernity. Camille Kapoor, (2011) clarified that the generation Y or echo boomers - now commonly referred to as the millennials - are those with the most distinct characteristics compared to other generations [24]. They are also known as the generations with the most variety in terms of characteristics.

Hawkins, D.I., dan Mothersbaugh, (2010) define the Y generation as the group of people born between years 1977 to 1994 [25]. Ordun, (2015) defined that defines the millennial generation as those who were born between 1980 and 2000 with optimistic view and they are considered as open minded, social, innovative, enthusiastic, determined, confident, motivated and smart [26].

\section{Conceptual Framework and The Hypothesis}

The study apply the paradigm in purchasing decision for a modest housing as figur 2 below.

The hypotheses that author formulated based on the data are as follows: $\mathrm{H} 1=$ There is a positive correlation of lifestyle on purchase decision $\mathrm{H} 2=$ There is a positive correlation of perception on purchase decision $\mathrm{H} 3=$ There is a positive correlation of motivation on purchase decision. $\mathrm{H} 4$ = There is a positive correlation of lifestyle, perception and motivation on the purchase decision. 


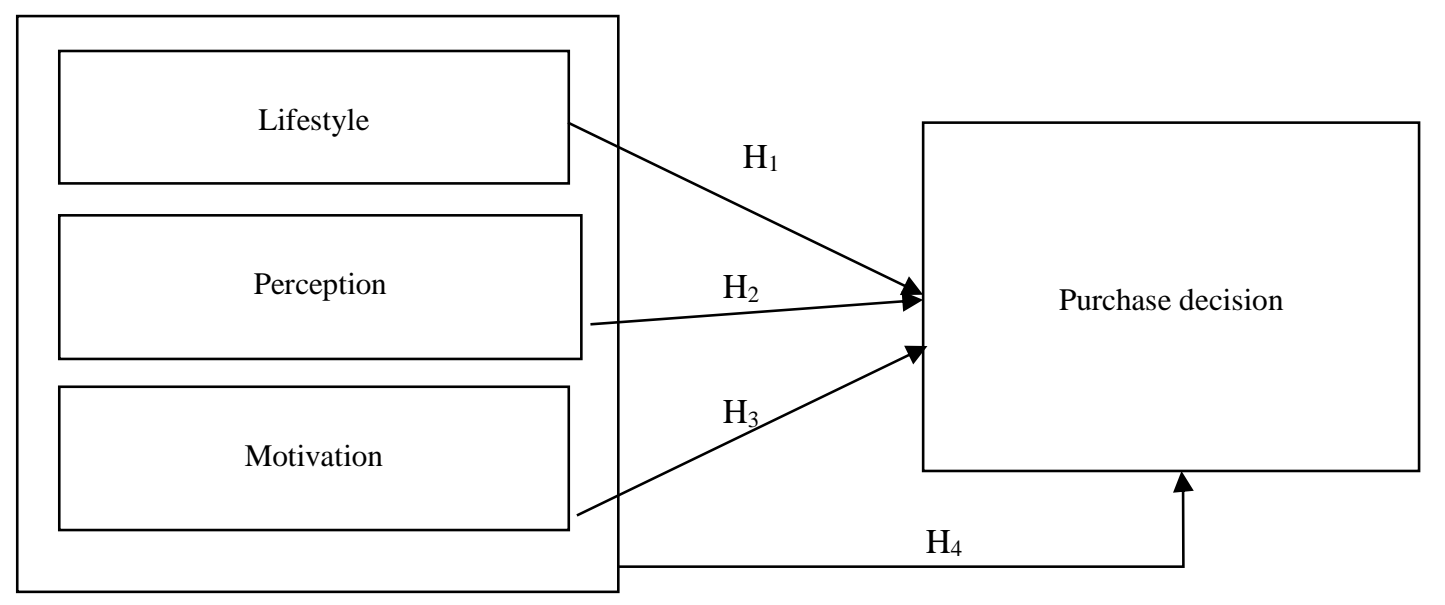

Fig. 2. Conceptual Framework

\section{Research Methodology}

It applied multiple regression analysis to find determining factors for those all independent variables. The respondents were the owners of the modest houses, the price lower than IDR $250 \mathrm{Mio}$, in Indonesia. The inquiry had done by an on-line questionnaire with google form, been up loaded throughout August to September 2017. The study applied purposive sampling method by controlling the first a hundred responses for the respondent ages of 30 to 40 . The variables utilized in the study were Lifestyle, Perception, Motivation, as independent variables, and the Purchase Decision as dependent variable.

\section{Research Findings}

Statistically it revealed that The Lifestyle variable $\left(\mathrm{X}_{1}\right)\left(\mathrm{t}_{\text {count }}=10,972\right.$; $\left.\mathrm{Sig}=0,000\right)$; if $T_{\text {count }}(10,972)>t_{\text {table }}(1,66)$ the $H_{0}$ is rejected. Value $\operatorname{Sig} .(0,000)<0,05$ the $H_{a}$ is accepted (hypotesis 1). Meaning that the variable lifestyle (X1) partially related and significantly effected the Purchase Decision (Y). Further, Perception $\left(\mathrm{X}_{2}\right)\left(\mathrm{t}_{\text {count }}=-0,647\right.$; Sig $\left.=0,519\right)$; if $t_{\text {count }}(-0,647)<t_{\text {table }}(1,66)$ the $H_{0}$ is accepted. If the Sig. $(0,519)>0,05$ the $H_{a}$ is rejected (hypothesis 2). Meaning that variable Perception or pride factor $\left(\mathrm{X}_{2}\right)$ partially related and insignificantly effected the Purchase Decision (Y).

Also, Motivation variable $\left(\mathrm{X}_{3}\right)\left(\mathrm{t}_{\text {count }}=3,286 ; \mathrm{Sig}=0,001\right)$; If $\mathrm{t}_{\text {count }}(3,286)>\mathrm{t}_{\text {table }}(1,667)$ the $\mathrm{H}_{0}$ is rejected; if the Value Sig. $(0,001)<0,05$ the $\mathrm{H}_{\mathrm{a}}$ is accepted (hypothesis 3 ). Meaning that the motivation variable (X3) partially related and significantly effected the Purchase Decision (Y) 
Table 1. Collinearity Statistics

\begin{tabular}{|c|c|c|c|c|c|c|c|}
\hline \multirow[b]{2}{*}{ Model } & \multicolumn{2}{|c|}{$\begin{array}{l}\text { Unstandardized } \\
\text { Coefficients }\end{array}$} & \multirow{2}{*}{$\begin{array}{c}\text { Standardized } \\
\text { Coefficients } \\
\text { Beta }\end{array}$} & \multirow[b]{2}{*}{$\mathrm{t}$} & \multirow[b]{2}{*}{ Sig. } & \multicolumn{2}{|c|}{$\begin{array}{l}\text { Collinearity } \\
\text { Statistics }\end{array}$} \\
\hline & $\mathrm{B}$ & Std. Error & & & & Tolerance & VIF \\
\hline 1 (Constant) & 5,519 & 1,357 & & 4,066 & .000 & & \\
\hline GAYA_HIDUP & .735 & .067 & .717 & 10,972 & .000 & .869 & 1,151 \\
\hline PERSEPSI &,- 041 & .064 &,- 041 & -647 & .519 & .933 & 1,072 \\
\hline MOTIVASI & 213 & .065 & 214 & 3,286 &, 001 & .876 & 1,142 \\
\hline
\end{tabular}

The life style and Motivation have a positive correlation with $\beta=.717$ and $\beta=.214$ and significant influence $(\mathrm{sig} .000$ and $.001<.005$ ) to purchasing decision. The study inferred that the lifestyle or economy factors and motivation or investment factors were the salient factors for the buying behavior in purchasing the modest housing. The perception or the pride factors, however, were not the issues for the millenial to buy it $(\beta=-.041)$, whilst it was insignificant.

Table 2. The Coefficients of Purchasing Decision Regression

\begin{tabular}{|c|c|c|c|c|c|}
\hline \multirow[b]{2}{*}{ Model } & \multicolumn{2}{|c|}{$\begin{array}{l}\text { Unstandardized } \\
\text { Coefficients }\end{array}$} & \multirow{2}{*}{$\begin{array}{c}\text { Standardized } \\
\text { Coefficients } \\
\text { Beta } \\
\end{array}$} & \multirow[b]{2}{*}{$\mathrm{t}$} & \multirow[b]{2}{*}{ Sig. } \\
\hline & $\mathrm{B}$ & Std. Error & & & \\
\hline 1 (Constant) & 5,519 & 1,357 & & 4,066 & .000 \\
\hline GAYA_HIDUP & .735 & .067 & .717 & 10,972 & .000 \\
\hline PERSEPSI & -.041 & .064 & -.041 & -.647 & .519 \\
\hline MOTIVASI & 213 & .065 & 214 & 3,286 &, 001 \\
\hline
\end{tabular}

Table 3. Model Summary for Purchasing Decisison Regression

\begin{tabular}{|l|c|r|r|r|}
\hline & & & & \\
Model & R & R Squareb & Adjusted R Square & Std. Error of the Estimate \\
\hline 1 & $.999 \mathrm{a}$ & .998 & .998 & .64591 \\
\hline
\end{tabular}


Table 4. Annova

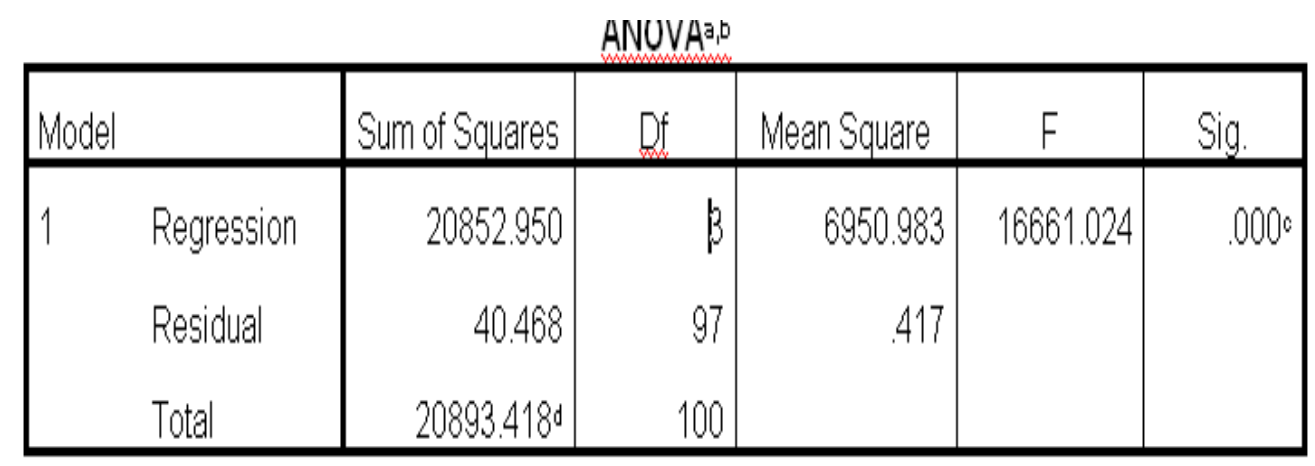

Table 4 and tabel 3 demonstrated that the determinant coefficient results or the Adjusted $R$ Square $\left(\mathrm{R}^{2}\right)$ is 0.998 or $99.8 \%$. In other words, $99.8 \%$ Purchase Decision (Y) is determined by the variables of Lifestyle $\left(\mathrm{X}_{1}\right)$, Perception $\left(\mathrm{X}_{2}\right)$, and Motivation $\left(\mathrm{X}_{3}\right)$, all together significantly effect the purchasing decision (hipotesis 4 ). The remaining $0.02 \%$ is determined by other factors not being discussed in this research.

\section{Conclusion and Discussion}

1. Lifestyle in the millennials partially has positive effect and significantly related to the Purchase Decision for modest housing.

2. Perception or pride of the millennials partially has negative effect and insignificantly related to the Purchase Decision of modest housing.

3. Motivation in investment of the millennials partially has positive effect and significantly correlated to the Purchase Decision on buying modest housing.

4. The study inferred that the lifestyle or economy factors and motivation or investment factors were the salient factors for the buying behavior in purchasing the modest housing. The perception or the pride factors, however, were not the issues for the millennials to buy the modest housing.

The author advises developers to consider lifestyle in the development of the affordable housing or the modest housing. This lifestyle factors could be in terms of more accessible location to office building, or at least close to public transportation hubs and other public facilities such as mall, culinary centers and other amenities. In addition, the invesment motivation also the salient factor for the millennials in purchasing modest housing. Consciquently, the investment interest rate is also an important variable for them to buy or not to buy the house. 


\section{References}

[1]M. R. Diamond, "The Meaning and Nature of Property: Homeownership and Shared Equity in the Context of Poverty,” Georg. Public Law Leg. Theory Res. Pap., vol. 112, 2009.

[2]L. S. Saw and T. H. Tan, "Factors Affecting the Purchase Decision of Investors in the Residential Property Market in Malaysia," J. Surv. Constr. Prop., vol. 5, no. 2, pp. 1985-7527, 2014.

[3]E. Mardanugraha and F. Mangunsong, "Final report," 2005.

[4]T. I. Bank et al., "International Bank for Reconstruction and Development," Development, pp. 2-3, 2008.

[5]A. M. Dickerson, "Millennials , Affordable Housing , and the Future of Homeownership," J. Afford. Hous., vol. 24, no. 3, pp. 435-466, 2016.

[6]Deloitte, "Deloitte Consumer Insights: The evolution of the Indonesian consumer," 2016.

[7]BPS Indonesia, "Publikasi Statistik Perumahan dan Permukiman," Jakarta, Indonesia, 2016.

[8]Statistics Indonesia, "Indonesia - Survei Sosial Ekonomi Nasional 2013," 2014.

[9]Rumah.com, "Review Properti," https://www.rumah.com/, Jakarta, Indonesia, 2017.

[10]Colliers International, “Jakarta Property Market Review,” 2017.

[11]P. Kotler and K. L. Keller, Marketing Management, vol. 22, no. 4. Prentice Hall Boston Columbus Indianapolis New York San Francisco Upper Saddle River, 2009.

[12]D. Grewal et al., "Understanding how to achieve competitive advantage through regulatory fit: a meta-analysis," Mark. Sci. Inst. Work. Pap. Ser. 2010, no. 10, 2010.

[13]2008. Kotler, P., Adam S., Denize, S., Armstrong, G., Principles of marketing, 4th ed. Frenchs Forest NSW: Pearson Education Australia, 2008.

[14]N. Kanjanawattanawong, "Rev. Integr. Bus. Econ. Res. Vol 3(NRRU) 129," Rev. Integr. Bus. Econ. Res., vol. 3, pp. 129-135, 2014.

[15]K. M. and Gibler and S. L. Nelson, "Consumer behaviour applications to real estate," 1998.

[16]P. W. Engel, J. F., Blackwell, R. D., \& Miniard, Consumer Behavior., Eight. Orlando: The Dryden Press., 1995.

[17]J. Krishnan, "Lifestyle - A tool for understanding buyer behavior," Int. J. Econ. Manag., vol. 5, no. 2, pp. 283-298, 2011.

[18]J. Pickens, "Attitudes and Perceptions,” Organ. Behav. Heal. Care, pp. 43-75, 2005.

[19]S. Quratulain and K. P. A. F. Karachi, "Consumer Perception and Buying Decisions(The Pasta Study),” Int. J. Adv. Res. Technol., vol. 1, no. 6, 2012.

[20]B. A. M. A.-H. Mohammad and A. P. M. Som, “An Analysis of Push and Pull Travel Motivations of Foreign Tourists to Jordan,” Int. J. Bus. Manag., vol. 5, no. 12, pp. 41-50, 2010.

[21]L. Guan, "Push and pull factors in determining the consumers 'motivations for choosing wedding banquet venues : A case study in Chongqing, China," 2014.

[22]S. Lee, "Vroom's expectancy theory and the public library customer motivation model," Libr. Rev., vol. 56, no. 9, pp. 788-796, 2007.

[23]V. Svatosova, "Motivation of Online Buyer Behavior," J. Compet., vol. 5, no. 3, pp. 14-30, 2013.

[24]N. S. Camille Kapoor, "Understanding and managing generational differences in the workplace.," Worldw. Hosp. Tour. Themes, vol. 3, no. 4, pp. $308-318,2011$.

[25]D. . . 11t. edition. Hawkins, D.I., dan Mothersbaugh, Consumer Behavior: Building Marketing Strategy, 11th ed. McGraw-Hill Education, McGraw-Hill, Irwin, 2010.

[26]G. Ordun, "Millennial (Gen Y) Consumer Behavior Their Shopping Preferences and Perceptual 